\title{
Antibodies to urinary tract pathogens in patients with spinal cord lesions
}

\author{
$\mathrm{C}_{\text {Moser }}{ }^{1}$, NJ Kriegbaum ${ }^{2}$, SO Larsen ${ }^{3}$, N Høiby ${ }^{1}$ and F Biering-Sørensen ${ }^{2}$ \\ Department of ${ }^{1}$ Clinical Microbiology and ${ }^{2}$ Centre for Spinal Cord Injured, Rigshospitalet, Copenhagen University \\ Hospital, and ${ }^{3}$ Department for Biostatistics, Statens Seruminstitut, Copenhagen, Denmark
}

\begin{abstract}
Chronic or recurrent urinary tract infection (UTI) is a significant problem for patients with spinal cord lesions (SCL). UTIs are thought to be a major factor in the development of reduced renal function. To investigate the pathogenesis 151 patients with SCL were included in this study during a 7 year period. Results of intravenous pyelography and isotope renography were recorded as well as the bladder emptying methods. One to seven blood samples were obtained from each patient and tested for plasma creatinine, and the presence of precipitating antibodies against Escherichia coli, Klebsiella pneumonia, Klebsiella ozaenae, Proteus mirabilis, Enterococcus faecalis and Pseudomonas aeruginosa. We found significant correlation between duration of SCL and precipitating antibodies against urinary tract pathogens (PAU) $(r=0.23, P<0.005)$, between plasma creatinine and PAU in patients with spina bifida $(r=0.64, P<0.01)$, between PAU and the number of positive urine cultures $(r=0.17 ; P<0.05)$ and a relation between abnormal urological findings and PAU. In addition, the PAU was significantly higher in patients with indwelling urethral catheters $(P<0.001)$. Thus it seems that PAU can be of prognostic value in SCL patients, and PAU might be an indicator for intensified treatment of recurrent UTI.
\end{abstract}

Keywords: spinal cord injuries; paraplegia; tetraplegia; spina bifida; recurrent infections; urinary tract infections precipitating antibodies

\section{Introduction}

Impaired renal function is still a major cause of morbidity in patients with spinal cord lesions (SCL). ${ }^{1-5}$ Although the pathogenesis is unclear it is thought to be secondary to recurrent urinary tract infections (UTI), frequently seen in these patients. $3,6-11$

It has previously been demonstrated that the occurrence of antibodies to bacterial antigens during chronic or recurrent infection (eg cystic fibrosis, endocarditis and lepra) may be of prognostic significance for the course of the disease in infected patients. ${ }^{12,13}$ Thus, the pulmonary deterioration in patients with cystic fibrosis is correlated to the levels of precipitating antibodies against Pseudomonas aeruginosa antigens. ${ }^{14}$ These findings have led to the hypothesis that infections, in which the defense mechanisms fail to eradicate the bacteria, may result in continuous stimulation of the immune system with a pronounced antibody response, resulting in formation of immune complex mediated inflammation and secondary tissue damage. ${ }^{12,13,15,16}$ We hypothesized that recurrent UTI would also induce precipitating antibodies against the offending pathogens and that the level of the antibody response may be correlated to

Correspondence: C Moser, Department of Clinical Microbiology 9301, The Centre for Laboratory Medicine and Pathology, Rigshospitalet, Juliane Mariesvej 22, Copenhagen, 2100-DK the tissue damage and thereby the impairment of the renal function.

In the present study, therefore, the occurrence of precipitating antibodies against urinary tract pathogens (PAU) in patients with SCL with neurogenic bladder dysfunction was investigated and correlated with the level of creatinine, number of UTI and the duration of SCL.

\section{Patients and methods}

One hundred and fifty-one patients with SCL including cauda equina lesions with neurogenic bladder dysfunction were included in the study during the period 1983-1990. There were 117 males $(77 \%)$ and 34 females (23\%). Of these, 102 had traumatic SCL. Of the 49 non-traumatic SCL, 20 were the result of spina bifida (SB), 13 tumors, seven transverse myelitis of non-infectious etiology, and nine others. Level of SCL in relation to diagnosis group is given in Table 1 . The age ranged from 1981 years, with a mean of 38 years. The age of the spina bifida patients ranged from 13-57 years (mean 23 years). The urine bladder emptying method used by the patients: suprapubic tapping $(n=49)$, abdominal pressure ('crede') $(n=36)$, intermittent catheterization $(n=12)$, indwelling catheter $(n=13)$ or uretero-ilio-cutaneo-stomia (am Bricker) $(n=10)$. Fourteen patients used a combination of suprapubic 
tapping and 'crede', two patients 'crede' and intermittent catheterization, two patients used both suprapubic tapping and intermittent catheterization and one patient used suprapubic tapping, 'crede' and intermittent catheterization. Twelve patients had normal or nearly normal bladder emptying. The urodynamic investigation showed the following bladder types: Supranuclear $(n=80 ;$ SB: 2), infranuclear $(n=40 ; \mathrm{SB}: 13)$, mixed $(n=20 ; \mathrm{SB}: 4)$ and not known for 11 (SB: 1). Depending on when the patients were included into the study, one to seven bloodsamples from each patient (median 3) were tested for serum creatinine and the occurrence of precipitating antibodies against Escherichia coli, Klebsiella pneumonia, Klebsiella ozaenae, Proteus mirabilis, Enterococcus faecalis and Pseudomonas aeruginosa as previously described. ${ }^{17-19}$ In brief, precipitating antibodies against bacteria were detected by crossed immunoelectrophoresis using water-soluble antigens obtained by sonication. Normal values for each of the six bacteria: E. coli: $0-2$ precipitins, $K$. pneumonia: $0-2$ precipitins, $K$. ozaenae: 0-2 precipitins, $P$. mirabilis: $0-2$ precipitins, $E$. faecalis: $0-2$ precipitins and $P$. aeruginosa: $0-1$ precipitins.

Precipitating antibodies against urinary tract pathogens (PAU) was calculated as the sum of the precipitins against the four Enterobacteriaceae ( $E$. coli, $K$ pneumonia, $K$. ozaenae, $P$. mirabilis), $4 \times$ precipitins against $E$. faecalis and $4 \times$ precipitins against $P$. aeruginosa. Chronic UTI induce antibody response to the offending pathogens. Due to taxonomic relationship between the species resulting in UTI, some of these antibodies cross-react with UTI bacteria other than the offending pathogen. ${ }^{15}$ For calculations it was therefore necessary to compensate by using a multiplicity factor for the species with low cross-reactivity. ${ }^{15}$

Urine cultures were performed at regular follow up visits every year or every second year. Some of the patients have in addition delivered urine for culturing when they had specific symtpoms of UTI. MannWhitney U-test, Spearmans rank-correlation and Fisher's exact test were used in the statistical analyses, and five per cent chosen as level of significance.

\section{Results}

Duration of SCL and PAU

There was a significant, although weak, correlation between the duration of the SCL $(5-63$ years, mean 17 years) and the PAU $(r=0.23 ; P<0.005)$ at the last examination (Figure 1). The same trend, however not statistically significant, was found by analyzing the diagnostic groups separately.

\section{$P A U$ and plasma creatinine}

In the 20 patients with SB the plasma creatinine correlated significantly with the PAU (mean 24.2) $(r=0.64 ; P<0.01)$ (Figure 2$)$. No significant correlation was found when all patients were included, and looking at the different bladder types, we did not find any significant correlation between PAU and plasma creatinine.

\section{$P A U$ and UTI}

We found a weak but significant correlation between PAU at the last examination and the number of

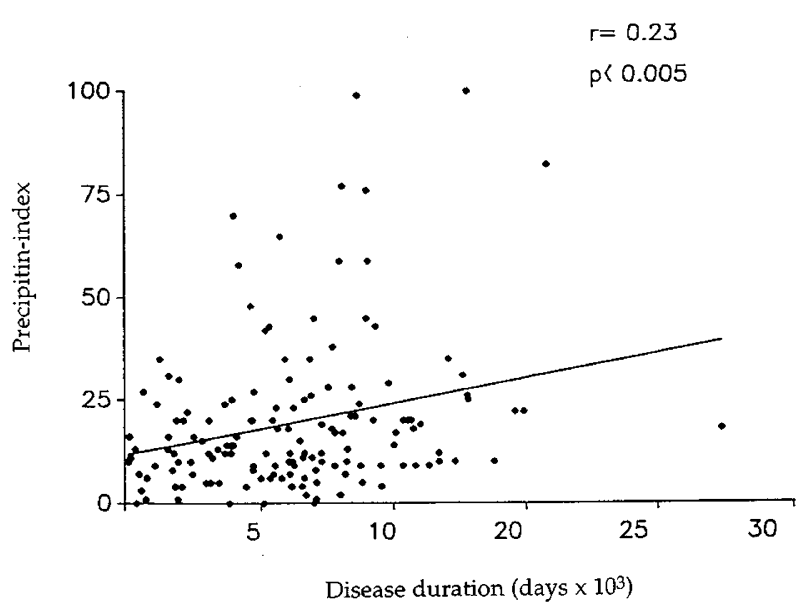

Figure 1 Correlation between the duration of spinal cord lesion and index for precipitating antibodies against urinary tract pathogens for all patients, at the last examination

Table 1 The spinal cord lesioned patients divided by diagnosis group and level of lesion. Age at first bloodsample

\begin{tabular}{lccccc}
\hline & & \multicolumn{2}{c}{ Level of lesion } & Lumbar \\
Group & Cervical & Thoracic & Sacral \\
\cline { 2 - 6 } (number) & Age & & & number \\
\hline Traumatic (102) & 38 & 43 & 48 & 11 & 0 \\
Non-traumatic (29) & 51 & 5 & 23 & 1 & 0 \\
Spina bifida (20) & 23 & 0 & 9 & 9 & 2 \\
Total (151) & 38 & 48 & 80 & 21 & 2 \\
\hline
\end{tabular}


positive urine cultures since the last examination or for the last 12 months $(r=0.17 ; P<0.05)$ (Figure 3$)$.

\section{Relation between PAU and urological findings}

Forty-six patients, with abnormal urological findings at the last examination (Table 2), had a significantly higher PAU (mean 27.2) compared to the 105 patients

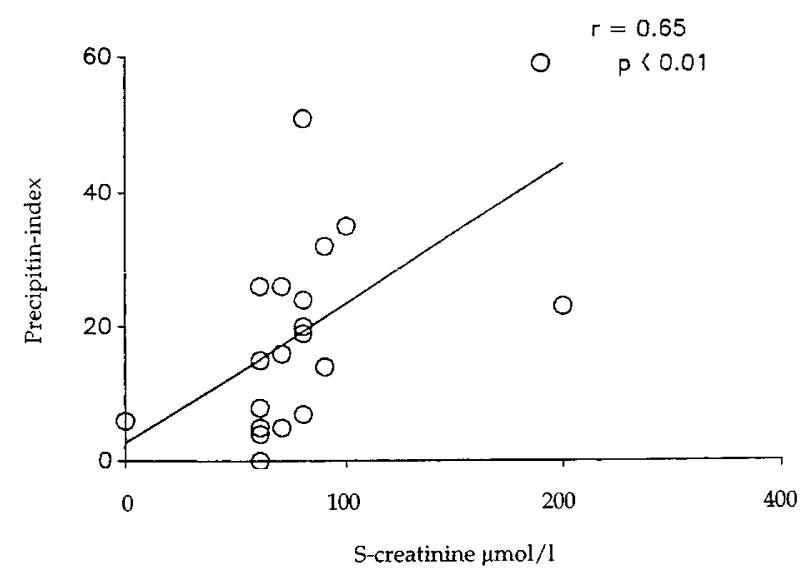

Figure 2 Correlation between index for precipitating antibodies against urinary tract pathogens and S-creatinine for the 20 patients with spina bifida with normal urological findings (mean 16.0) $(P<0.001)$. Significantly more patients with SB lesion had abnormal urological findings at the first examination for PAU $11 / 20(55 \%)$, compared to patients with other SCL, $16 / 131 \quad(12 \%) \quad(P<0.0005)$. Though the difference was less pronounced at the last examination for PAU $(12 / 60(60 \%)$ vs $34 / 131(26 \%))$ it was still significant $(P<0.005)$.

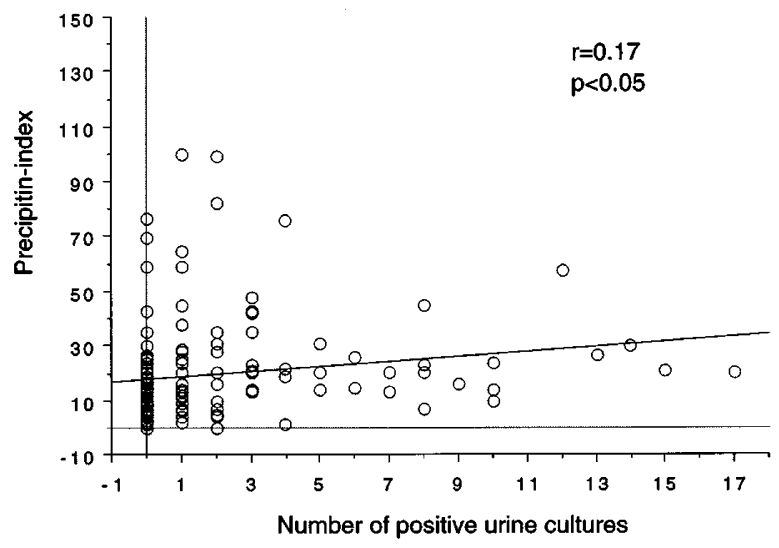

Figure 3 Correlation between index for precipitating antibodies against urinary tract pathogens and number of positive urine cultures since last examination or within the last 12 months

Table 2 Abnormal findings at intravenous pyelography of 18 patients and isotope renography of 34 patients at last precipitin examination. Six patients had abnormal findings at both investigations, ie the total number of patients with abnormal findings was 46

\begin{tabular}{ll}
\hline Intravenous pyelography $(\mathrm{n}=18)$ & Renography $(\mathrm{n}=34)$ \\
\hline Stones in upper urinary tract $(n=6)$ & Decreased renal function unilateral $(n=18)$ \\
Stones in bladder $(n=5)$ & Decreased renal function bilateral $(n=1)$ \\
Pyelonephritis sequelae unilateral $(n=1)$ & Imparied outlet upper urinary tract unilateral $(n=13)$ \\
Pyelonephritis sequelae bilateral $(n=2)$ & Impaired outlet upper urinary tract bilateral $(n=11)$ \\
Stasis/dilated upper urinary tract unilateral $(n=6$ & \\
Stasis/dilated upper urinary tract bilateral $(n=2)$ & \\
\hline
\end{tabular}

Table 3 The mean precipitin index for precipitating antibodies against urinary tract pathogens (PAU) in relation to duration of spinal cord lesion (SCL), +/ - use of indwelling urethral catheter, and normal (or not investigated) versus abnormal urological findings at last examination

\begin{tabular}{|c|c|c|c|c|}
\hline \multirow[b]{2}{*}{$\begin{array}{l}\text { Duration of } S C L \\
\text { (years) }\end{array}$} & \multicolumn{4}{|c|}{ Mean precipitation index $(P A U)$} \\
\hline & $\begin{array}{l}- \text { indwe } \\
\text { Normal } \\
(\mathrm{n}=97)\end{array}$ & $\begin{array}{l}\mathrm{n}=138) \\
\text { Abnormal } \\
(\mathrm{n}=41)\end{array}$ & $\begin{array}{l}+ \text { indw } \\
\text { Normal } \\
(\mathrm{n}=8)\end{array}$ & $\begin{array}{c}(\mathrm{n}=13) \\
\text { Abnormal } \\
(\mathrm{n}=5)\end{array}$ \\
\hline$<2$ & $11(7)$ & $(0)$ & $11(1)$ & $(0)$ \\
\hline $2-9$ & $12(23)$ & $12(2)$ & $28(2)$ & 19 (2) \\
\hline $10-19$ & $13(40)$ & $26(17)$ & $11(3)$ & $41(2)$ \\
\hline$>20$ & $22(27)$ & $26(22)$ & $55(2)$ & $100(1)$ \\
\hline
\end{tabular}

Only significant increased level of PAU in the 102 patients with traumatic SCL 
$P A U$ and indwelling urethral catheter

In the 102 patients with traumatic SCL, the PAU was significantly higher in patients with indwelling catheters $(P<0.001)$ (Table 3).

\section{Discussion}

In the present study we found that increased levels of precipitating antibodies to bacterial antigens occurred in patients with recurrent urinary infections. The 46 patients with abnormal urological findings, had significantly higher PAU than the 105 patients with normal urological investigation. This seems to reflect impaired renal function, since the serum creatinine in 20 patients with SB correlated significantly with PAU. Spina bifida patients have had impaired bladder function since birth in contrast to the other SCL patients. In accordance with this, significantly more SB patients had abnormal urological investigation compared to patients with other SCL. Furthermore, there was a significant correlation between the duration of SCL and the level of PAU. The finding that SCL patients with time have an increased risk of having decreased nephrological function is not new. ${ }^{1-11}$ The interesting thing is that there is a relation between abnormal urological findings, decreased nephrological function and increasing PAU. This suggests that the recurrent infection, at least in part, is responsible for the reduced renal function. In concordance with this we found significantly higher PAU in patients with the type of catheterization which gives the highest risk of bacterial infections, namely indwelling urethral catheters and we found a significant correlation between PAU and the number of UTIs. In spite of the irregular urine cultures performed we still found a significant correlation between PAU and UTI. Therefore, it would be of interest to proceed from this study to a prospective study on this issue. A positive correlation between bacterial pathogens and antibodies is well known in asymptomatic or clinical gastric Helicobacter pylori infections, where successful clearance of the infection is correlated with a decline of IgG antibodies, as soon as 1 month after treatment, whereas reinfection gives a rise of $\mathrm{IgG}$ antibody level. ${ }^{20}$ Since high and increasing antibody response in chronic pulmonary infections have been found to correlate to poor prognosis, ${ }^{14}$ the present findings may indicate that a similar prognostic value of antibodies could be existing in SCL patients. If this is the case, a more aggressive/prophylactic treatment of the UTI could be the consequence in patients with increasing levels of antibodies to UTI pathogens. $^{21}$ In addition, further studies (eg cytokines, CRP, WBC, ESR, renal biopsies with detection of immune complexes etc) are needed to investigate the pathogenesis of the UTI and renal impairment in patients with increased antibody response to UTI pathogens.

\section{References}

1 Barton CH, Vaziri ND, Gordon S, Tilles S. Renal pathology in end-stage renal disease associated with paraplegia. Paraplegia 1984; 22: $31-41$.

2 DeVivo MJ, Kartus PL, Rutt RD, Fine PR. Cause of death for patients with spinal cord injuries. Arch Intern Med 1989; 149: $1761-1766$

3 Hartkopp A, Brønnum-Hansen H, Seidenschnur A-M, BieringSørensen F. Survival and cause of death after traumatic spinal cord injury. Spinal Cord 1997; 35: 76-85.

4 Najenson $\mathrm{T}$ et al. Upper urinary tract in patients after traumatic spinal cord injury. Paraplegia 1969; 7: 85-96.

5 Viera A, Merrit JL, Erickson RP. Renal function in spinal cord injury: A Preliminary report. Arch Phys Med Rehabil 1986; 59: $257-259$.

6 Erickson RP, Merritt JL, Opitz JL, Ilstrup DM. Bacteriuria during follow-up in patients with spinal cord injury: 1 . Rates of bacteriuria in various bladder emptying methods. Arch Phys Med Rehabil 1982; 63: 409-412.

7 Kuhlemeier KV, Stover SL, Lloyd LK. Prophylactic antibacterial therapy for preventing urinary tract infections in spinal cord injury patients. J Urol 1985; 134: 514-517.

8 Pedersen SS, Hørbov S, Biering-Sørensen F, Høiby N. Peroral treatment with ciprofloxacin of patients with spinal cord lesions and bacteriuria caused by multiply resistant bacteria. Paraplegia 1990; 28: $41-47$.

9 Ruutu M, Lehtonen T. Urinary tract complications in spinal cord injury patients. Ann Chirugiae Gynaecologiae 1984; 73: 325-330.

10 Stover SL, Lloyd LK, Waites KB, Jackson AB. Urinary tract infection in spinal cord injury. Arch Phys Med Rehabil 1989; 70: $47-54$.

11 Stover SL, Lloyd LK, Waites KB, Jackson AB. Neurogenic urinary tract infection. In: Young RR, Woolsey RM (eds). Diagnosis and Management of Disorders of the Spinal Cord. 1st edn. WB Saunders Company: Philadelphia, 1995, pp 198-210.

12 Høiby N, Koch C. Pseudomonas aeruginosa infection in cystic fibrosis and its management. Thorax 1990; 45: $881-884$.

13 Høiby N, Döring G, Schiøtz PO. The role of immune complexes in the pathogenesis of bacterial infections. Ann Rev Microbiol 1986; 40: $29-53$.

14 Høiby N. Pseudomonas aeruginosa infection in cystic fibrosis: Diagnostic and prognostic significance of Pseudomonas aeruginosa precipitins determined by crossed immunoelectrophoresis. A survey. Acta Pathol Microbiol Scand 1977; Suppl 262 (C): 3 96.

15 Høiby $\mathrm{N}$ et al. Taxonomic applications of crossed immunoelectrophoresis. Internat J Syst Bact 1987; 37: 229-240.

16 Høiby N, Schiøtz PO. Immune complex mediated tissue damage in the lungs of cystic fibrosis patients with chronic Pseudomonas aeruginosa infection. Acta Paediatr Scand 1982; Suppl 301: 63 73.

17 Høiby N. Antibodies against Pseudomonas aeruginosa in serum from normal persons and patients colonized with mucoid and non-mucoid Pseudomonas aeruginosa: results obtained by crossed immunoelectrophoresis. Acta Path Microbiol Scand 1977; Sect C 85: $142-148$.

18 Høiby N. Microbiology of lung infections in cystic fibrosis patients. Acta Paediatr Scand 1982; Suppl 301: $33-54$.

19 Høiby N, Hertz JB. Precipitating antibodies against Escherichia coli, Bacteroides fragilis ss, thetaiotaomicron and Pseudomonas aeruginosa in serum from normal persons and cystic fibrosis patients, determined by means of crossed immunoelectrophoresis. Acta Paediatr Scand 1979; 68: $495-500$.

20 Oderda G et al. Eighteen month follow up of Helicobacter pylori positive children treated with amoxycillin and tinidazole. Gut 1992; 33: $1328-1330$.

21 Biering-Sørensen F et al. Ciprofloxacin as prophylaxis for urinary tract infection: Prospective, randomized, cross-over, placebo controlled study in patients with spinal cord lesion. J Urology 1994; 151: $105-108$. 